\title{
Isolation of Fungi from Nature in the Region of Botucatu, State of São Paulo, Brazil, an Endemic Area of Paracoccidioidomycosis
}

\author{
MR Montenegro/ ${ }^{+}$, M Miyaji*, M Franco, K Nishimura*, KI Coelho, Y Horie**, \\ RP Mendes***, A Sano*, K Fukushima*, D Fecchio
}

Departamento de Patologia, Faculdade de Medicina, UNESP, 18618-000 Botucatu, SP, Brasil *Research Center for Pathogenic Fungi and Microbial Toxicoses, Chiba University, Chiba, Japan **Natural History Museum and Institute, Chiba, Japan ***Departamento de Moléstias Infecciosas e Parasitárias, Faculdade de Medicina,

UNESP, Botucatu, SP, Brasil

In an attempt to isolate Paracoccidioides brasiliensis from nature 887 samples of soil from Botucatu, $S P$, Brazil, were collected cultured in brain heart infusion agar supplemented with dextrose, in potato dextrose agar and in yeast extract starch dextrose agar, all with antibiotics, at $25^{\circ}$ and $37^{\circ} \mathrm{C}$. Five thermo-dependent dimorphic fungi morphologically resembling P. brasiliensis were isolated; two from armadillo holes; further studies of the biology, antigenicity and genetic features of the five dimorphic fungi are necessary to clarify their taxonomy and their possible relation to P. brasiliensis. In addition, 98 dematiaceous fungi and 581 different species of Aspergillus spp. were also isolated. Our findings emphasize that armadillos and their environment are associated with thermo-dimorphic fungi and confirm the ubiquity of pathogenic dematiaceous fungi and Aspergillus spp.

Key words: ecology - nature - pathogenic fungi - Paracoccidioides brasiliensis

There is uncertainty about the natural habitat of Paracoccidioides brasiliensis (Pb). It is assumed that the fungus lives saprophytically in nature; conidia, asexual spores of the fungus, may disperse in the air and infect man by the inhalatory route. $\mathrm{Pb}$ is capable of surviving in soil (Medina \& Bodziak 1949) and in vegetal debris (Lacaz 1949). Is has been isolated from the soil in Brazil (Shome \& Batista 1963), Argentina (Negroni 1966) and Venezuela (Albornoz 1971), but results could not be replicated. The fungus has also been isolated from dogfood in Brazil (Ferreira et al. 1990), from intestinal tract of bats (Grose \& Tramsitt 1965), and from antartic penguin feces (Gezuele 1989); again results have not been confirmed.

The epidemiology of Paracoccidioidomycosis ( $\mathrm{Pb}$ mycosis) that effects mainly rural workers, the high frequency of reactive $\mathrm{Pb}$ skin tests in animals living on soil when compared with tree dwelling animals (Costa et al. 1995), the finding of the agent

Work supported by FAPESP and Research Center for Pathogenic Fungi and Microbial Toxicoses.

${ }^{+}$Corresponding author. Fax: +55-14-821.2348

Received 18 January 1996

Accepted 6 August 1996 in internal organs of armadillos (Naiff et al. 1986), the increased rate of positivity to paracoccidioidin in indians after they were exposed to dust from coffee plantations in a deforested area (Wanke et al. 1992), all point to the soil as one of the most likely habitat of the fungus.

In 1993, the Paracoccidioidomycosis Study Group of Botucatu - UNESP Campus and a group of Japanese mycologists from the Research Center for Pathogenic Fungi and Microbial Toxicoses, Chiba University, Japan, carried out a cooperative work to study the ecology of $\mathrm{Pb}$ in Botucatu and neighbourhood. They also tried to isolate pathogenic dematiaceous fungi which are the causative agents of chromomycosis and Aspergillus species which produce mycotoxins. As is well known, chromomycosis has frequently been reported from Latin America and there are several reports on the isolation of pathogenic dematiaceous fungi from nature in the area (Melin \& Nannfeldt 1934, Trejos 1954, Salfelder et al. 1968, Gezuele et al. 1972, Mackinon et al. 1973, Nishimura 1994). Furthermore, mycotoxins may be dangerous contaminants of food and aflatoxin a known carcinogen was first extracted in Great Britain from ground nuts imported from Brazil (Asplin \& Carnaghan 1961, Sargeant et al. 1961).

The present paper describes the preliminary results of this ecological survey. 


\section{MATERIALS AND METHODS}

Table I describes the localities and number of samples collected. The work was done during winter (July and August 1993), the dry season in Botucatu.

Pro-Verde is a suburb of Botucatu where flowers are cultivated; Pratania is a village surrounded by farms $35 \mathrm{~km}$ to the northwest of Botucatu; Edgardia is an experimental farm of the UNESP Agricultural School where several crops are cultivated; Vitoriana is a village around $30 \mathrm{~km}$ to the southeast of Botucatu also surrounded by farms. We collected 887 samples of soil and rotten plants.

Aproximately $20 \mathrm{~g}$ of soil were collected into a plastic bag with a spoon, from fields, forests, farms, armadillo holes and other sites and transported to the laboratory (Table I). The same procedure was followed for rotten plants.

Isolation of thermo-dependent dimorphic fungi and pathogenic dematiaceous fungi was carried out as follows. One to $2 \mathrm{~g}$ of soil were transferred to a sterile $10 \mathrm{ml}$ plastic tube; $5 \mathrm{ml}$ of sterile saline containing antibiotics (50-100 mg of chloramphenicol, $10^{6}$ units of penicillin, $167 \mathrm{mg}$ of streptomycin and $500 \mathrm{mg}$ of cyclohexamide per liter) were then added, mixed by agitation and set for $30 \mathrm{~min}$; $0.5 \mathrm{ml}$ was collected from the middle part of the soil suspension and placed on brain heart infusion agar (BHIA, Difco) supplemented with $1 \%$ dextrose and the same antibiotics. A drop was spread on the surface of the agar medium and incubated at $37^{\circ} \mathrm{C}$ for 10 days. The same procedure was done with two other media: potato dextrose agar (PDA, Difco) and YPSS (yeast extract 1\%, soluble starch $1 \%$, dextrose $1 \%$ and agar $2 \%$ ), with the same antibiotics. The plates were incubated at $25^{\circ} \mathrm{C}$ and $37^{\circ} \mathrm{C}$ for 10 days.

For isolation of Apergillus spp., the same media were used, with no cyclohexamide.

The suspected colonies were subcultured on Sabouraud dextrose agar (SDA), BHIA and PDA at $25^{\circ} \mathrm{C}$ and $37^{\circ} \mathrm{C}$ and checked grossly and microscopically. Thermo-tolerance and nitrate utilization tests were also done to further identify the pathogenic dematiaceous fungi.

\section{RESULTS}

Isolation of thermo-dependent dimorphic fungus - Five yeast like fungal isolates which resembled $\mathrm{Pb}$ were obtained from BHIA and YPSS at $37^{\circ} \mathrm{C}$ (isolates no. $170,212,268,328-1$ and 328 2 ). The isolates grew slowly and formed wrinkled, folded, glabrous, whitish colonies. Mycelial colonies on PDA at room temperature for a few months showed similarities to those of $\mathrm{Pb}$; they grew slowly as glabrous, leathery, flat, wrinkled, folded and flocose to velvety colonies colored from white to beige and brown, with little tufts of aerial mycelium. They also had central fissures, another common feature of $\mathrm{Pb}$ colonies.

Microscopically the five isolates formed chlamydospores on SDA at $25^{\circ} \mathrm{C}$ for 28 days and converted from mycelial to yeast form at $35^{\circ} \mathrm{C}$ on

TABLE I

Localities, sites and number of samples collected in a survey to study fungi in nature in Botucatu

\begin{tabular}{|c|c|c|c|c|c|c|}
\hline \multirow[b]{2}{*}{ Site } & \multicolumn{5}{|c|}{ Localities } & \multirow[b]{2}{*}{ Total } \\
\hline & Pro-Verde & Pratania & Edgardia & Vitoriana & $\begin{array}{l}\text { Botanical } \\
\text { Garden }^{a}\end{array}$ & \\
\hline Field $^{b}$ & 48 & 74 & 88 & 14 & 0 & 224 \\
\hline Plantation $^{c}$ & 9 & 50 & 0 & 52 & 0 & 111 \\
\hline Forest $^{d}$ & 23 & 78 & 3 & 0 & 0 & 104 \\
\hline Farm $^{e}$ & 0 & 46 & 0 & 27 & 0 & 73 \\
\hline Water side ${ }^{f}$ & 7 & 40 & 7 & 5 & 0 & 59 \\
\hline Road side ${ }^{g}$ & 30 & 21 & 5 & 2 & 0 & 58 \\
\hline Armadillo hole & 21 & 20 & 11 & 3 & 0 & 55 \\
\hline Rotten plant & 10 & 22 & 6 & 0 & 0 & 38 \\
\hline Bush $^{h}$ & 11 & 3 & 1 & 3 & 0 & 18 \\
\hline Ant hole & 7 & 8 & 0 & 2 & 0 & 17 \\
\hline Others $^{i}$ & 8 & 47 & 1 & 0 & 74 & 130 \\
\hline Total & 174 & 409 & 122 & 108 & 74 & 887 \\
\hline
\end{tabular}

$a$ : Botanical Garden of UNESP Campus; $b$ : an area covered with different types of grass and a few isolated trees; $c$ : cultivated area (coffee, sugar cane, oranges); $d$ : eucalyptus or pine; $e$ : neighborhood of farmers house; $f:$ margin of ponds; $g$ : shoulders of unpaved road; $h$ : area covered with several different types of mixed local small trees; $i$ : insect nests, lawns, egg shells, bird droppings, animal food. 
BHIA. Multiple buddings were seen on isolate 268 . Table II shows the localities and sites from where they were collected; three of them (isolates 212, 328-1, 328-2) were isolated from soil of Pratania and two (isolates 170 and 268), from armadillo holes also in Pratania.

TABLE II

Thermally dependent dimorphic fungi isolated from soil in Botucatu

\begin{tabular}{cl}
\hline Isolate number $^{a}$ & \multicolumn{1}{c}{ Site } \\
\hline 170 & Armadillo hole \\
212 & Field \\
268 & Armadillo hole \\
$328-1$ & Eucalyptus forest \\
$328-2$ & Eucalyptus forest \\
\hline
\end{tabular}

$a$ : all five thermo-dimorphic fungi were isolated from Pratania.
Isolation of pathogenic dematiaceous fungi Ninety-eight black colonies were obtained (Table III). They were identified as Curvularia lunata: 3 , Exophiala spinifera: 55, Fonsecaea pedrosoi: 2, $F$. pedrosoi-like fungi: 14, Phialophora verrucosa: 6, Exophiala sp.: 11, Ramichloridium anceps: 3, Rinocladiella atrovirens: 3 and Veronaea botryosa: 3 .

Isolation of Aspergillus ssp. - Five hundred and eighty one of the 831 samples (56 of the 887 samples were not cultivated fot technical reasons) had Aspergillus spp. They were found in all localities and sites studied. Table IV summarizes the findings.

Table $\mathrm{V}$ shows numbers and percentage of $A s$ pergillus spp. and black fungi collected from soil and from rotten plants. The majority $(80.7 \%)$ of our samples were collected from soil and we did not collect rotten plants in two localities.

TABLE III

Pathogenic dematiaceous fungi isolated from nature in Botucatu

\begin{tabular}{lcccccr}
\hline & \multicolumn{5}{c}{ Localities } & \\
\cline { 2 - 5 } Fungal isolate & Pro-Verde & Pratania & Edgardia & Viroriana & B. Garden ${ }^{a}$ & Total \\
\hline Curvularia lunata & 1 & 1 & 1 & 0 & 0 & 2 \\
Exophiala spinifera & 11 & 18 & 13 & 5 & 8 & 55 \\
Exophiala sp. & 2 & 5 & 2 & 1 & 1 & 11 \\
Fosecaea pedrosoi & 1 & 1 & 0 & 0 & 0 & 2 \\
F. pedrosoi-like & 7 & 5 & 1 & 0 & 1 & 14 \\
Phialophora verrucosa & 2 & 1 & 2 & 0 & 1 & 6 \\
Ramichloridium anceps & 1 & 0 & 1 & 0 & 0 & 3 \\
Rhinocladiella atrovirens & 0 & 2 & 1 & 0 & 0 & 3 \\
Veronaea botryosa & 1 & 0 & 2 & 0 & 0 & 3 \\
\hline Total & 26 & 33 & 22 & 6 & 11 & 98 \\
\hline
\end{tabular}

$a$ : Botanical Garden of UNESP Campus.

TABLE IV

Number of Aspergillus spp. isolated ${ }^{a}$ from nature in Botucatu

\begin{tabular}{|c|c|c|c|c|c|c|}
\hline & \multicolumn{5}{|c|}{ Localities } & \multirow[b]{2}{*}{$\begin{array}{l}\text { Total } \\
831^{c}\end{array}$} \\
\hline & $\begin{array}{c}\text { Pró-Verde } \\
\text { n-174 }\end{array}$ & $\begin{array}{c}\text { Pratania } \\
\text { n-353 }\end{array}$ & $\begin{array}{c}\text { Edgardia } \\
n-122\end{array}$ & $\begin{array}{l}\text { Vitoriana } \\
\text { n-108 }\end{array}$ & $\begin{array}{l}\text { B. Garden } \\
\text { n-74 }\end{array}$ & \\
\hline A. fumigatus & 102 & 221 & 88 & 64 & 58 & 533 \\
\hline A. niger & 83 & 130 & 45 & 45 & 51 & 354 \\
\hline A. terreus & 19 & 63 & 48 & 38 & 29 & 197 \\
\hline A. neoelli & 12 & 13 & 4 & 6 & 8 & 43 \\
\hline A. flavus & 6 & 32 & 6 & 9 & 15 & 68 \\
\hline Emericella $^{d} \mathrm{sp}$. & 26 & 34 & 10 & 6 & 21 & 97 \\
\hline Neosartorya ${ }^{e} \mathrm{sp}$. & 5 & 12 & 1 & 4 & 25 & 47 \\
\hline Thielavia ${ }^{f} \mathrm{sp}$. & 2 & 16 & 5 & 5 & 11 & 39 \\
\hline Others ${ }^{g}$ & 6 & 5 & 0 & 2 & 2 & 15 \\
\hline
\end{tabular}

$a$ : more than one species was isolated from the same sample; $b$ : Botanical Garden of UNESP Campus; $c$ : for technical reasons 56 of the 887 samples collected were not cultivated for Aspergillus; $d$ : teleomorph of A. nidulans; $e$ : Ascomyceta, Plectomyces, Eurotiales; its anamorph is A. fumigatus; $f$ : teleomorph genus of Eurotiales; $g$ : already published (Horie et al. 1995a, b). 
TABLE V

Number of samples (n) and number of positive Aspergillus and black fungi isolates obtained from soil and rotten plants by locality

\begin{tabular}{|c|c|c|c|c|c|c|}
\hline & \multicolumn{5}{|c|}{ Localities } & \multirow[b]{2}{*}{ Total } \\
\hline & Pró-Verde & Pratania & Edgardia & Vitoriana & B. Garden ${ }^{a}$ & \\
\hline Soil & $n-164$ & $n-331$ & $n-1162$ & $\mathrm{n}-108$ & $\mathrm{n}-74$ & $\mathrm{n}-793$ \\
\hline Aspergillus spp. & 105 & 227 & 94 & 79 & 63 & $\begin{array}{c}568 \\
(71.6 \%)\end{array}$ \\
\hline Black fungi & 15 & 25 & 17 & 6 & 9 & $\begin{array}{c}72 \\
(9.1 \%)\end{array}$ \\
\hline Rotten plants & $\mathrm{n}-10$ & $n-22$ & $n-6$ & 0 & 0 & $n-38$ \\
\hline Aspergillus spp. & 2 & 10 & 1 & 0 & 0 & $\begin{array}{c}38 \\
(34.2 \%)\end{array}$ \\
\hline Black fungi & $\begin{array}{c}4 \\
(40.0 \%)\end{array}$ & $\begin{array}{c}3 \\
(13.6 \%)\end{array}$ & $\begin{array}{c}1 \\
(16.7 \%)\end{array}$ & 0 & 0 & $\begin{array}{c}7 \\
(18.4 \%)\end{array}$ \\
\hline
\end{tabular}

a: Botanical Garden of UNESP Campus.

\section{DISCUSSION}

Botucatu is located around $800 \mathrm{~m}$ above sea level, has 1,463 $\mathrm{mm}$ of rain fall per year and an average temperature of $19^{\circ} \mathrm{C}$ (Marques et al. 1983), which are the environmental features of the endemic areas of Pbmycosis (Restrepo-Moreno 1994). Indeed, the disease is frequent in the area and a large proportion of the rural population is reactive to paracoccidioidin (Carandina \& Magaldi 1974). The knowledge that $\mathrm{Pb}$ has been isolated from soil and plants as well as the finding of the fungus in armadillos, a common animal in Brazil, led us to look for the agent in nature in the rural area of Botucatu to better understand how man is infected and to try to define the fungus natural habitat. The methodolody used provided the opportunity to isolate several other possibly pathogenic fungi as dematiaceous black fungi and Aspergillus.

The thermo-dependent fungi that in culture had gross and microscopic similarities with $\mathrm{Pb}$ were isolated from Pratania an area in which more than $10 \%$ of the population is paracoccidioidin positive (Marques et al. 1983). Furthermore, several patients with PCM seen at the UNESP University Hospital live in Pratania. Two of these isolates were collected from soil of armadillo's holes (Table II), an interesting finding that correlates with the isolation of the agent in Amazonian armadillos (Naiff et al. 1986). We are in the process of studying the biology, antigenicity and virulence of these isolates as well as expanding the ecological survey to collect further soil samples from other armadillo holes. The results of these studies will be published in the future.
The fact that only five thermo-dependent dimorphic fungi were isolated from 887 samples indicates their scarcity and may explain the difficulties to isolate from nature the causative agent of Pbmycosis. If the morphological likeness to $\mathrm{Pb}$ of these dimorphic fungi is associated with antigenic similarities, exposure to them may interfere with the immune status of the local population leading to alterations on host-parasite relationship with consequences in the evolution of Pbmycosis.

Potentially pathogenic dematiaceous fungi of nine different species were also isolated (Table III). Among them, F. pedrosoi, $P$. verrucosa and $E$. spinifera are important causative agents of chromomycosis and phaeophycomycosis. As these diseases usually occur by the penetration of the causative agent through skin wounds, it is relevant to clarify their habitat in nature and the enviromental circumstances in which they may infect man.

Trejos, in 1954, first succeeded in isolating $F$. pedrosoi from soil in Costa Rica; later on the fungus was isolated from soil and plant debris in Venezuela, Uruguay and Japan (Salfelder et al. 1968, Gesuele et al. 1972, Iwatsu et al. 1981, Okeke \& Gugnani 1986). Nishimura (1994) and Nishimura et al. (1989) investigated the ecology of pathogenic fungi in natural and living environments in Colombia, Venezuela, Brazil, China and Japan and succeeded in isolating various species of pathogenic dematiaceous fungi including $F$. pedrosoi, $P$. verrucosa and $E$. spinifera. We also succeeded in isolating two strains of E. pedrosoi and 14 strains of $F$. pedrosoi-like fungi.

$P$. verrucosa is found around the world, on decayed wooden materials. The species was first 
isolated from wood pulp by Melin and Nannfeldt (1934). Since then many successful isolations have been reported (Emmons 1954, Wang 1965, Klite et al. 1965, Udagawa \& Horie 1971, Gesuele et al. 1972, Dixon et al. 1980, Iwatsu et al. 1981, Okeke \& Gugnani 1986, Nishimura et al. 1989). We isolated six strains of $P$. verrucosa in Botucatu.

E. spinifera was isolated from nature by Mackinnon et al. (1973), by Dixon et al. (1980) and Nishimura (1994). According to these surveys, E. spinifera prevails in South America and China. We isolated 55 strains of E. spinifera. Our findings indicate that E. spinifera also prevails in Botucatu and neighbourhood.

Another interesting result is the isolation of $V$. botryosa from nature in Botucatu. This is the first report from South America; up to now, the species has only been successfully isolated in New Guinea and China (Nishimura et al. 1989).

Five hundred and eighty-one Aspergillus spp. were isolated from 831 culture samples (Table IV). As is well known, several species of Aspergillus produce mycotoxins particularity aflatoxin, one of the dangerous carcinogenous mycotoxin (Asplin \& Carnaghan 1961, Lancaster et al. 1961, Sargeant et al. 1961). A serious accident with chickens due to aflatoxin occured in Great Britain caused by groundnuts imported from Brazil. Therefore it is important to investigate the ecology of Aspergillus spp. in Brazil.

Horie et al. (1989, 1991) studied the distribution of Aspergillus species in Colombia, Venezuela and Brazil. In our survey various species of Aspergillus were isolated from nature. Studies to evaluate their ability to yield mycotoxins are under way.

The data on Table $\mathrm{V}$ indicate that Aspergillus spp. were isolated from $71.6 \%$ of the samples of soil and were present in all the localities studied. Black fungi, however were more frequently isolated from rotten plants. The small number of samples from these plant debris do not permit any valid comparison or conclusion. Furthermore plant debris were not collected from all of the localities studied.

We are now studying more samples collected from pasture grass, ant holes, earth worms and plant debris as well as from armadillos. Our preliminary results confirm our above described findings and are very suggestive of the close association of $\mathrm{Pb}$ and armadillos.

\section{REFERENCES}

Albornoz MCB 1971. Isolation of Paracoccidioides brasiliensis from rural soil in Venezuela. Sabouraudia 9: 248-253.

Asplin FD, Carnaghan RBA 1961. The toxicity of cer- tain groundnut meal for poultry with special references to their effect on ducklings and chickens. Vet Record 73: 1215-1219.

Carandina L, Magaldi C 1974. Inquérito sobre blastomicose sul americana pela intradermo reação em uma comunidade rural do municípo de Botucatu. Rev Saúde Púb 8: 171-179.

Costa EO, Diniz C, Fava Netto C, Arruda C, Dagli MLZ 1995. Delayed hypersensitivity test with paracoccidioidin in captive Latin American wild animals. J Med Vet Mycol 33: 33-39.

Dixon DM, Shadomy HJ, Shadomy S 1980. Taxonomy and morphology of dematiaceous fungi isolated from nature. Mycopathologia 70: 153-161.

Emmons CW 1954. The significance of saprophytism in the epidemiology of the mycoses. Trans NY Acad Sci 17: 157-166.

Ferreira MS, Freitas LH, Lacaz LS, Del Negro GM, Aielo NT, Garcia MN, Assis CM, Salebian A, HerisVaccari EM 1990. Isolation and characterization of a Paracoccidioides brasiliensis strains from dog food probably contaminated with soil in Uberlândia, Brazil. J Med Vet Mycol 28: 253-256.

Gezuele E 1989. Aislamiento de Paracoccidioides sp. de heces de penguino de la Antartida. Proceedings IV Encuentro Internacional sobre Paracoccidioidomicosis, Caracas, Venezuela.

Gezuele E, Mackinnon JE, Conti-Diaz IA 1972. The frequent isolation of Phialophora verrucosa and Fonsecaea pedrosoi from natural sources. Sabouraudia 10: 266-273.

Grose E, Tramsitt JR 1965. Paracoccidioides brasiliensis recovered from the intestinal tract of three bats (Artibetus literatus) in Colombia S. A. Sabouraudia 4: 124-125.

Horie Y, Miyaji M, Nishimura K, Taguchi H, Yamaguchi H, Udagawa S 1989. Distribution of Emericela species in soil of South America, with special references to their production of sterigmatocystin and the related metabolites. Proc Jpn Assoc Mycotoxicol 29: 21-26.

Horie Y, Miyaji M, Nishimura K, Taguchi H, Udagawa S 1991. Distribution of Aspergillus species, members of the section Fumigati in South America soil and their proteolytic activity. Jpn J Med Mycol 32: 313-321.

Horie Y, Miyagi M, Nishimura K, Franco MF, Iabuki Coelho K 1995a. Two new species of Neosartoria from Brazilian soil. Mycoscience 36: 159-165.

Horie Y, Miyagi M, Nishimura K, Franco MF, Iabuki Coelho K 1995b. New and interesting species of Neosartoria from Brazilian soil. Mycoscience 36: 199-204.

Iwatsu T, Miyaji M, Okamoto S 1981. Isolation of Phialophora verrucosa and Fonsecaea pedrosoi from nature in Japan. Mycopathologia 75: 149-158.

Klite PD, Kelly Jr HB, Diercks FH 1965. A new soil sampling technique for pathogenic fungi. Amer $J$ Epidemiol 31: 124-130.

Lacaz CS 1949. Novos dados em relação à blastomicose sul americana e seu agente etiológico. Rev Med Cir S Paulo 9: 303-340. 
Lancaster MC, Jenkins FP, Philip JM 1961. Toxicity associated with certain samples of groundnuts. $\mathrm{Na}$ ture (4793) 191: 1095-1096.

Mackinnon JE, Gesuele E, Conti-Diáz IA, de Giménez AC 1973. Production of capsule and conidia by yeast-like cells of Phialophora spinifera and Phialophora jeanselme. Sabouraudia 11: 33-38.

Marques SA, Franco MF, Mendes RP, Silva NCA, Bacili D, Curcelli ED, Feracin ACM, Oliveira CS, Tagliarini JV, Dillon NL 1983. Aspectos epidemiológicos da paracoccidioidomicose na área endêmica de Botucatu (São Paulo, Brasil). Rev Inst Med Trop São Paulo 25: 87-92.

Medina H, Bodziak Jr C 1949. Contribuição ao ciclo extraparasitário do Paracoccidioides brasiliensis II. Cultura do $P$. brasiliensis em terra e influência exercida pelo pH. Arg Biol Tecnol 4: 3-8.

Melin E, Nannfeldt JA 1934. Researchs into the blueing of ground wood-pulp. Svenka Skosvardsfören Tidskr 32: 397-585.

Naiff RD, Ferreira LCL, Barret TV, Naiff MF, Arias JR 1986. Paracoccidioidomicose enzootica em tatus (Dasypus novencinctus) no Estado do Pará. Rev Inst Med Trop São Paulo 28: 19-27.

Negroni P 1966. El Paracoccidioides brasiliensis vive saprofiticamente en el suelo argentino. Prensa Med 53: 2831-2832.

Nishimura K 1994. The ecology of pathogenic dematiaceous fungi. Jpn J Med Mycol 35: 385-391.

Nishimura K, Miyaji M, Taguchi H, Wang DL, Li RY, Meng ZH 1989. An ecological study of dematiaceous fungi in China, p. 17-20. Proceedings of the $4^{\text {th }}$ International Symposium of the Research Center for
Pathogenic Fungi and Microbial Toxicoses, Chiba University, Chiba.

Okeke CM, Gegnani HC 1986. Studies on pathogenic dematiaceous fungi. Isolation from natural sources. Mycopathologia 94: 19-25.

Restrepo-Moreno AM 1994. Ecology of Paracoccidioides brasiliensis, p. 121-130. In M Franco, CS Lacaz, A Restrepo-Moreno, G Del Negro (eds). Paracoccidioidomycosis, CRC Press, Boca Raton, FL.

Salfelder K, Schwarz A, Romero A, de Liscano TR, Zambrano Z, Diaz I 1968. Habitat de Nocardia asteroides, Phialophora pedrosoi y Cryptococcus neoformans in Venezuela. Mycopath Mycol Appl 34: 144-154.

Sargeant D, Sheridan A, O'Kelly J, Carnaghan RBA 1961. Toxicity associated with certain samples of groundnuts. Nature 192: 1096-1097.

Shome SK, Batista AC 1963. Occurence of Paracoccidioides brasiliensis in the soil in Recife, Brazil. Rev Fac Med Univ Federal Ceará 3: 90-94.

Trejos A 1954, cited from Ajello L 1956. Soil as natural reservoir for human pathogenic fungi. Science 1236: 876-879.

Udagawa S, Horie Y 1971. Taxonomical notes on mycogenous fungi I. J Gen Appl Microbiol 17: 141159.

Wang CJK 1965. Fungi of pulp and paper in New York, State Univ Coll, Forestry Tech Pub No. 87, p. 96.

Wanke B, Coimbra CEA, Franciscone do Vale AC, Lana R, Zancope-Oliveira RM 1992. Paracoccidioidin sensitivity among Tupi-Mundé Amerindians of Brazilian Amazon. Rev Argentina Mycol 15: 21. 